\title{
Friendship and Youth Activism in Pre-revolutionary Egypt
}

\author{
Henri Onodera
}

\section{Introduction}

In April 2007, I joined Muhammad (26) and Said (28) in a small, dimly-lit restaurant in downtown Cairo. A leftist political activist, Muhammad was a sharp-witted character who proclaimed himself an anarcho-communist. Although his online writing stirred up the occasional controversy, he was respected in activist circles for his political blogging and for his persistent and courageous actions at the front line of democratic struggle, including fighting riot police and baltagiyya (plain clothes 'thugs' hired by the police), which had resulted in his being detained several times over the past few years. His friend Said, a young Arab Nationalist, was currently unemployed but active in independent groups. We entered into diversified and rather heated debates on current politics in the noisy, crammed and smoky atmosphere. The restaurant, which was also one of the few downtown places that served beer to its clientele, provided a realm of experience that provided a stark contrast to the $5^{\text {th }}$ Cairo Anti-War Conference at the Journalists' Syndicate which I had just left. The latter event had been held annually since the outbreak of the Iraq war, gathering participants from Egypt and abroad, and represented one of the major collective efforts by the otherwise factionalized political opposition in Egypt.

Muhammad and Said boycotted the Cairo Conference in 2007. The main reason for their disengagement was the active and public role the Muslim Brotherhood took in both the conference's organizing committee and during the conference itself. The two abstainers could not fathom why some of their fellow Leftists, such as Trotskyist Revolutionary Socialists, should want to co-organize the conference in alliance with the Brotherhood, even on the pretext that revolution in Egypt could not materialize without collaborating with by far the largest opposition movement in the country. On the other hand, Muhammad admitted that he and Said were not entirely natural companions either: he usually hates Nasserists and Arab nationalists, such as Said, for idolizing Gamal Abdel Nasser, Egypt's charismatic leader of the 
post-independence era. Muhammad admitted, however, that he appreciated the vast socioeconomic reforms aimed at building an educated middle class which had taken place under Nasser in the 1950s and 1960s and had also enabled upward social mobility for his parents. Yet the regime had simultaneously hit hard at Nasser's political rivals and dissenters for a number of years, including leading figures of Egypt's communist movement. Muhammad further deplored what he saw as nepotistic practices in current Nasserist groups, a line of criticism that soon encompassed most opposition parties and also some NGOs. Said, having had dire experiences of party politics himself, could only agree.

These kinds of friendship relations were forged under particular historical circumstances. Prior to the January 25, 2011 revolution, Egypt had witnessed an unprecedented wave of pro-democracy mobilization during Hosni Mubarak's presidency since 1981. During the previous decade, scores of young people, who were mostly born and raised under Mubarak's rule, participated in public dissent against the ruling National Democratic Party (NDP), at times forging new youth coalitions at the fringes of larger processes of contentious politics, such as the pro-democracy movement and burgeoning labourers' strike movements. In this chapter, I do not reiterate what has been stated time and again, that the 2011 uprisings were long in the making and the younger generations of Egypt's political opposition played important roles during the preceding decade (e.g., El-Mahdi 2014; Cole 2014). Nor do I suggest that the important roles friendship relations play in public mobilization is a novel phenomenon in Egypt. Rather, I cast a closer look at the dynamics of trust, belonging and everyday solidarities, or what are often regarded as the 'ideal' values of friendship, in the context of oppositional youth activism in the late Mubarak era. More generally, my focus rests on young Cairenes' lived experiences in the context of being involved in the wider pro-democracy movement that emerged in Egypt public life in the 200os. This was mainly dominated by the so-called 'secular' opposition, including various Leftist, Liberal and Arab Nationalist orientations, and thus coexisted with the more weighty opposition, namely, the Muslim Brotherhood, whose role as the largest and most organized opposition movement cannot be overlooked (Wickham 2002). Thus, the restricted focus in this chapter does not aim to belittle the role of the Islamists in contentious politics in the late Mubarak era; rather, it offers a glimpse into the everyday lives of those 'youth activists' some years before they were made famous and celebrated due to the revolutionary events in 2011 and beyond. As will be shown, friendship relations were for them in many ways invaluable in the volatile circumstances of opposition politics but, at the same time, a conspicuously fragile source for their continued collective actions. 


\section{Values of Friendship}

Despite the salient importance of friends in the everyday lives of young Egyptian activists, there is little research on the issue. My interest in friendship emerged during 12 months of ethnographic fieldwork on youth activism in Cairo between 2007 and 2011 (Onodera 2015). Regardless of their political involvement or lack thereof, it was clear that most young people in Egypt - as elsewhere - cherished the company of good friends. This observation, in all its banality, assists the recognition that, in the lifeworlds of young Egyptians who have learned to live in relative autonomy from their natal families, friendship ties forged at school, university and through leisure activities provide immediate experiences of trust, reciprocity and shared everyday existence. The relative (and historical) lack of ethnographic research on friendship partly stems from the scholarly preoccupation with kinship, although, as is often pointed out, the differences between these modes of social belonging cannot be taken for granted (Desai and Killick 2013b, 4-8; Grätz 2011, 359-361). At the least, Bell and Coleman suggest, the analytic of friendship can serve the aim of examining "social relations that may include but are not reducible to kinship; that are sustained beyond single or short-term encounters; that involve the search for some form of sentiment or at least empathy and common ground between persons" (1999b, 16). In comparison to the ascribed dimension of being a member of one's family, friendship relations seem, they argue, to be

defined solely on the basis of the social contract which really exists and is continually worked upon: participation depends on the relationship created over time between the particular people involved, while what brings people together in friendship may not be what keeps them together.

BELL and COLEMAN 1999b, 6

In public political life, it is hard to overestimate the importance of friendship relations in the lives of young Egyptian activist in the late 2000s. Acting as they were in the contentious sphere of politics where the perpetual state oversight of, and security infiltration into, their daily lives was a real concern, friendship relations provided them with vital experiences of trust, loyalty and belonging. At pivotal moments, such as in clashes with the police or in detention, good friends were those who could be trusted and whose solidarity could be counted upon. Undoubtedly, there was a tacit deal among young activists to go and protest in the case of anyone getting arrested, but at these junctures, individuals were wont to rely on the fact that, at the minimum, good friends would try and drag them from the arms of the Central Security Forces, if possible; they 
would certainly chase the police wagon so as to locate the exact police station to which they were being taken. In cases of detention, close friends were actively involved in contacting family members and journalists, designing online banners and circulating messages over the Internet so as to make the case as public as possible. Friends would also be active in helping to organize solidarity protests calling for release and, later, a welcome home party.

For the young activists, acts of public dissent - such as illegal street protesting, graffiti and political blogging - in themselves served to differentiate them from most Egyptians, who actively disengaged from anything 'political' so as to avoid reactions from the police state. Sharing moments of dissent, of facing injustice and of everyday solidarities served to forge concrete friendship relations that could endure over time. Muhammad and Said befriended one another while being confined in the same cell after having been detained during a street protest in 2006. Said's large family, encompassing a number of siblings, brought in various kinds of food almost daily which he then shared with fellow inmates, amounting to a 'feast' in Muhammad's opinion. Despite the odds stacked against them of ideological strife and political rivalry, and their different friendship circles, they gradually developed a sense of acceptance of one another, and caught up occasionally at opposition events or, as in the late April evening of 2007 mentioned above, their preferred restaurant. They had many stories to share and reminisce about due their participation in the pro-democracy movement. Often labelled the 'Kifaya' Movement (Arabic for 'Enough!'), this had emerged into Egypt's public life in the run-up period to the presidential elections in 2005. At least momentarily, it managed to conjoin several, even competing, opposition parties and groups against Mubarak, including Liberals, Arab Nationalists, Leftists and some Islamist opposition politicians. They collectively rejected the prospect of Mubarak's fifth six-year term in office and his alleged manoeuvres to pave the way for a presidential career for his youngest son Gamal Mubarak (Browers 2007; Shorbagy 2007).

Egyptian youth activism had evolved on parallel lines with wider protest movements since the turn of the millennium (Shehata 2008, 2011; El-Mahdi 2014). Among the pioneering youth movements, in which Muhammad and Said both participated, was one called Youth for Change (shabāb min ajl al-taghyirr) that was established in early 2005. Its members, involving both partisan and independent youth, acted as a semi-official 'youth wing' of the wider Kifaya movement, and spearheaded new forms of nonviolent protest. Effectively, they decentralized protest activities from central Cairo to impoverished residential areas, and included elements such as flash-mobs and street theatre, with the direct aim of connecting local grievances (such as poor services and lack of housing) to the wider goals for democratic reform. Despite the patriarchal 
norms in Egyptian public space, the movement also included a considerable number of young women, although they generally came from wealthier family backgrounds in comparison with their male peers. The loosely affiliated bloggers, among them Muhammad, gained new roles and visibilities online; their personal dissent, reaching ever growing audiences at home and abroad, was new in Egypt's political life, and so were their innovative ways of combining street stunts with up-to-date imageries, videos and stories on the Internet (Fahmi 2009; Onodera 2009, 2011). Although friendship between political rivals, such as Leftists and Islamists, was rare in the late 200os, the younger-generation bloggers of the Muslim Brotherhood gradually got to know bloggers from other political groups and orientations through their shared online practices and oppositional stances with regards the NDP and Mubarak's rule, as well as through participating in civil society workshops on digital activism in Egypt (e.g., Lynch 2007).

\section{Everyday Sociality}

As important as it is to recognize the vital role played by democratic struggle in the lives of the young activists, it is also essential to bear in mind that periodic street protesting, online campaigns, awareness raising stunts, public seminars and other engagements with political dissent occupied only one aspect of everyday existence. During in-between moments, which actually amounted to most of the time, many would meet friends in places of their preference, giving rise to the daily question: Where to sit down, and with whom? The young activists, who lived in various parts of the capital city, and whose everyday trajectories involved criss-crossing the metropolis, normally congregated in different parts of the centre where several political parties, NGOs and trade unions have their headquarters, and where the main sites for public protest and social congregation are located. In this context, the repeated acts of 'sitting together' (na'ud ma' ba'd) were important moments for re-creating and managing friendship relations that involved negotiating social proximities between one's self and others, and also offered prime opportunities to hear the latest news, recap past events, devise future engagements and joke around while there was little else to do. Sharing and co-enduring the idle moments of boredom can be in itself very meaningful (e.g., Schielke 2008).

In other words, being a young activist in the late Mubarak era was not only about the 'high' moments of democratic struggle; it was also about leisure, and involved hanging out with friends in places and moments in which protest narratives were circulated, shared experiences told and retold and political 
subjectivities mutually constructed. During the heyday of the anti-Mubarak mobilization in the mid-20oos, the downtown quarter of Al-Bursa in particular became a central hub for the everyday trajectories of young opposition activists (El Kadi and ElKerdany 2006, 364-366; Onodera 2015, 150-154). The quarter consisted of a pedestrian area - itself a rarity in overcrowded Cairo that housed a string of relatively inexpensive street-level coffee shops, or $a h \bar{a} w \bar{\imath}$ (sing. ahwa), that were filled with a constant buzz of life and the 'to-and-fro' of clientele, friends, colleagues and associates from various backgrounds: from young professionals and students to foreign expatriates, local artists, musicians and other breeds of 'cultured people'. Journalists from private newspapers would come after office hours with the latest gossip and news, before it made the headlines the following day. Young men and women could socialize with relative ease, unlike in the more localized and male-dominated ahāwī in popular, working class $(s h a b i)$ quarters of Cairo where cross-gender socializing and, for instance, the sight of young women smoking cigarettes and socializing with unrelated young men could potentially create a minor stir. Moreover, the old colonial-era buildings, the streets named after national heroes and the statues erected in their memory, cater to a sense of a glorious history: one of liberation and national pride. It could be seen as 'hybrid' urban space (Nederveen Pieterse 2009) in that it conjoined nostalgia for a glorious past, for freedom and the country's intellectual life and a sense of cosmopolitanism, with popular sensibilities and sociability - and relatively low prices.

For the young from outside Cairo, visiting places like Al-Bursa was a musthave experience in order to gain a sense of the capital city's 'activist scene' and the buzz of its political life. Members of different political groups, such as Liberals, Communists and Nasserists, passed numerous evenings there with fellow activists, including both 'friends' and 'foes'. Contentious conversations would occasionally flare up within and between different gatherings, and seating arrangements were modified accordingly. Young activists would leave their tables to join political events such as protests and seminars, only to return afterwards to recount their views and fresh experiences, and to plan future actions.

Due to the fact that the activist meetings and socializing often took place late in the evening, the activists' opportunities to attend were highly gendered. Whereas young men were relatively free from family oversight, young women often had home 'curfews' and, due to patriarchal norms, were expected to stay within the safe contours of studies, work or domestic life, especially in the evenings. On the other hand, the period of prolonged adolescence - or, for some, that of 'waithood' (Singerman 2007; Honwana 2012) - allowed relative leeway and increased opportunities to take part in intense social networking whenever 
it was possible. The Internet, and especially Facebook and other social networking sites, also alleviated these differential opportunities based on gender since young women could better participate in online discussions from home.

Indeed, in the late 200os, the changing patterns of online communication and networking have also brought tangible changes to how young Egyptians negotiate not only their dissent activities, but also their friendship relations. While the issue of online friendships goes beyond the scope of this chapter, it is mentioned here to remind us that the shared experiences of the 'wired' activists were no longer only based on daily encounters but, increasingly, on those mediated to growing publics through the new information and communication technologies (ICTs) (Herrera 2014). However, the need for face-to-face interaction among young activists had not disappeared. On the one hand, it was common knowledge that the Internet was a precarious means of communication due to digital surveillance and hacking, and phone conversations could be tapped by the security services. On the other, relations of trust, solidarity and group belonging required sustained face-to-face interactions so as to be verified and re-created, a phenomenon that particularly concerns the political sphere in which alliances and informal networks could be volatile and fast-changing. Although the members of Youth for Change managed to gain new political roles and visibilities during the electoral period in 2005, the renewed police pressure in the following year, coupled with internal conflicts between partisan and independent youth, resulted in the group's gradual disintegration. The members waged their last collective protest activities in April and May 2006 in support of two prominent judges, who claimed that the 2005 elections had been rigged. Moreover, the group's internal elections for the positions of general coordinator and incumbents of the various committees had turned into heated spectacles.

\section{Shifting Alliances}

Returning to the spatial aspects of the young activists' social interactions, urban places like Al-Bursa provided important sites for re-creating friendship relations in the late Mubarak era, but the rather romanticized notion outlined above of one of the social hubs of Cairene activists' daily trajectories was only part of the picture. During my time in Egypt, I encountered rather contradictory attitudes towards Al-Bursa. Some appeared to have poignant feelings about no longer voluntarily going to the area, while not choosing to explain why; others, however, were much more explicit. "Al-Bursa is like sewage," said Mahdi, citing a characterization common among his friends with which he 
agreed, adding: "It is a place for things, of course, to be decided, for some plans to be made, but not always for the best of the country." In his grim view, it was the prime arena where careerist youth waged plots against others, where the 'rumour mill' went into higher gear, and where it was impossible to remain neutral in terms of one's allegiance and loyalty:

If you go there you get involved - if not directly, it will be an indirect process, and if not fast, it will take a longer time. But, still at the end, what will happen to you is that you will get an infection. It is a very bad infection; it's a terrible disease.

In other words, his view was that spending time in these spaces would sooner or later result in an entanglement in contradictory webs of social relations which were seldom easy to navigate without taking up positions against one person or another. Because friendship relations were important sites of trust, belonging and solidarity in contentious politics, and involved daily flows of social, economic and emotional investments, the moments and processes leading to the fracture of friendship - or what had been perceived as such by at least one of the participants - had long-term repercussions in individuals' lives. Ismail remembers the painful experiences of prolonged detention during the Judges affair in 2006, when people he considered friends chose to disown him on ideological and personal grounds. Some even went as far as declaring him a disbeliever (humma kaffarūnī'). He was subjected to psychological and physical torture during detention which, coupled with the sense of betrayal, left him temporarily traumatized after release, and unable to return to 'normal' life.

In summer 2008, Walid, an aspiring journalist, considered himself a member of a nascent youth movement called April 6 Youth (shabāb 6 april), one of the most long-lasting oppositional youth movements in the run-up to 2011. The movement conjoined former Youth for Change members and previously apolitical youth, and promoted similar street tactics to Youth for Change, but their dissent was channelled through its Facebook group to a greater extent - calling for a general strike on April 6, 2008, for example, in solidarity with the workers' movement in the Nile Delta city of al-Mahalla al-Kubra. Walid was frustrated with the youth movement whose members, in his opinion, still talked too much, performed few concrete actions and, for the most part, met with others in downtown cafes. Airing his practical knowledge about friendship in the contested field of youth activism more generally, he explained that he saw a clear distinction between two forms of friendships that prevailed among young activists: acquaintanceship ('ilāqa, lit. a 'relation') and friendship (șadāqa). 
He explained that young activists usually have a large number of acquaintances with whom they meet regularly and engage in oppositional activities. They may appear to be close friends but their alliances are mostly forged in order to defend specific political positions or opinions and, especially, to pursue their personal interests (mașälih shakhșiyya). Thus, acquaintances stand in contrast to what Walid sees as true friendship, which is characterized by mutual loyalty, affection or love and genuine interest in the other's wellbeing. In comparison, Walid's view of acquaintanceship is that it is more instrumental and often constituted in opposition to others. Such relations, he contended, usually last as long as the grounds for these tactical alliances are in place, but, in the politicked and fast-paced sphere of youth activism, acquaintances often prove interstitial, giving way to new alliances. Similarly to Youth for Change, the April 6 Youth movement was already factionalizing by the summer of 2009, due to arguments over its internal governance and its responses to the sympathetic reception it enjoyed abroad, especially in the United States. By 2010, when Mohamed ElBaradei, the former IAEA chief, was gathering wide support behind his potential candidacy in the presidential elections planned for 2011, the youth movement had fragmented and given way to a number of off-shoot groups that began to organize on their own. At the same time, however, a number of young people, either former members or affiliated with the Muslim Brotherhood, participated in the pro-ElBaradei campaign, forging new friendships and alliances with more secular-oriented youth activists in the run-up period to the 2011 uprisings.

Lived realities seldom enable a clear-cut analytical separation between the instrumental and affective modes of friendship, although such divisions may inform local meanings of friendship among the activists themselves. At stake is the acknowledgement of what Tilo Grätz (2011) reviews in studies of friendship in Africa more generally: that affective and instrumental (or functional) modes of friendship should not be seen as mutually exclusive but, rather, as contingent upon time, place and social situation. Another possible assumption about friendship is related to the agency involved in maintaining friendship relations over time: there is, in particular, a risk of reproducing powerful assumptions about freedom, choice and individualism that are often valorized in studies based on Western middle-class experience (Grätz 2011; Allan 1989; Bell and Coleman 1999a; Desai and Killick 2013a). When studying friendship relations, as Allan cautions, the aspect of choice should be at least balanced with that of constraint, as both are embedded in and shaped by wider social, political and economic processes (Allan 1989, 30-48). I have suggested that although oppositional youth activism was expanding prior to 2011 it encompassed relatively 
small social circles where activists knew one another, and frequented the same cafes, political events and street demonstrations.

Interestingly, soon after Youth for Change had dissolved, Egyptian researcher Amr Abdelrahman $(2007,189)$ observed that the main pattern for the emergence of 'Kifaya youth' was in the form of sporadic and scattered friendship groups, or shilal (sing. shilla). He suggests viewing shilla socialities in parallel with more corporatist relations and party affiliations:

This intimate period of shilla formations (al-hâla al-shilaliyya al-hamìma) was remembered by the majority with a deep sense of nostalgia for the past that, in comparison, seems far distant from the present state of recession (hâlat al-rukūd al-ḥalizya) which is dominated by partisan activities.

ABDELRAHMAN 2007, 189

In Egypt, a shilla is best translated as a 'group of friends' or 'friendship clique' that is forged through schooling, army and the like, and potentially ties its members together for life. As such, it refers to closely-knit groups of friends a longstanding and widespread form of group formation among young Egyptians. Several scholars have argued for the centrality of these informal networks in Egypt's public political life (Springborg 1975; Migdal 2001; Sakr 2002, 842). Robert Springborg $(1975,1978)$, who has written relatively extensively on shilla formations in Egyptian politics in the post-independence era, describes them in the context of Egyptian trade unions as "small groups of friends united by bonds of personal, economic, and/or political interest ... It is shillas, rather than large formal organizations ... that perform crucial functions in the Egyptian political system" (Springborg 1978, 275-276).

On the face of it, shilal appear to be informal networks which mediate personal and collective experiences of reciprocity, solidarity and obligation and which can be operationalized as "the framework for effective political, social, and economic action" (Eickelman 2002, 319). Belonging to a shilla potentially secures its members, through informal channels, resource-filled, yet exclusive, everyday connectedness - or wāsț - to associational life and formal political institutions. The latter represents a prevalent form of 'social capital' that is needed in order to gain access to services, benefits and social exchange systems. The recreational shilal, common among university students, highlight socially sanctioned forms of mixed-gender gathering which channel friendship as well as courtship practices. For young university students in the 1980 , Sherifa Zuhur observed that shilal also provided "social connections, fallbacks, introductions to mates, and favour exchanges. Young women and men feel 
an essential need to 'belong' inside or outside the family circle" (Zuhur 1992, 105-106). However, as soon as they enter the public political life and get entangled in vertical relations of power and patronage, shilla formations provoke increasingly negative connotations - on the part of outsiders especially - of shared interest groups or even political cliques (Springborg 1975).

However, as much as the aspect of instrumentality in friendship relations is often emphasized in the existing literature on shilla formations in Egyptian society, it is important to acknowledge that in the lives of young Cairenes they can be as much about joy and everyday conviviality as politics (de Koning 2009). In other words, sometimes members of a given shilla meet for recreation and leisure and, at other times, for more predetermined collective action in pursuit of their particularistic goals. The more recreational shilal may revolve around leisure activities, such as football (or sport fan culture), as well as certain tastes and forms of consumerism. The more affluent and cosmopolitan youth, for example, can find resonance in globally circulating tastes and commodities such as progressive rock, pizza or online movies, adopting lifestyle choices distinguishing them from those who do not have access to such luxuries.

At the same time, due to their public anti-regime stances, the activists were in many ways 'deviant' characters in society, which in itself confined them to rather narrow social urban spaces in central Cairo. Because oppositional activism was regarded in such a detrimental light by society, some concealed their political activism on the university campus, or within their families and the home neighbourhood. This choice involved selective self-exposure in everyday life, which stemmed partly from the goal of circumventing police surveillance but was also, for some, about avoiding potential social ostracism by their nonpoliticized peers. Huda - a young university student - told me that once she began to engage in political activism, her friends at the university abandoned her socially, to the point where her potential boyfriend called her a 'crazy girl' (magnüna) and other fellow students with whom she normally 'hung out' on the campus began to avoid her. She was briefly detained in April 2008, and soon afterwards joined the April 6 Youth movement; in 2008, Huda considered herself lucky because her parents allowed her to participate in it. Many of her friends concealed their political involvement at home and could not take part in the group's meetings late in the evenings due to parental curfews.

In the context of activism, shilla-based internal politics sometimes leads to dire experiences and disillusionment with regards those once considered as friends. Mahdi had received his share of 'back-stabbing' in the ranks of Youth for Change, and his characterization of Al-Bursa was the most extreme I encountered, yet it resonates with other views of the 'symptomatic' qualities of Egyptian politics in general. One would bemoan that "Political life in Egypt 
is ill," (al-hayā al-siyāsiyya fı mașr marìda) and another, "There is no love in politics" (mafish hubb fi al-siyāsa). While the more pessimistic accounts encompassed the undertakings of the ruling elite, these charges also targeted the political opposition, and the field of youth activism was not immune to partisan interests, personal differences and ideological strife. A popular Egyptian proverb - "Your friend swallows stones for you[r sake], and your enemy wishes for your mistakes" (Habībak yibla' lak al-zalat, wa 'aduwwak yitmannā lak alghalat) - is indicative of the degree of intensity placed on friendship solidarities, which were of heightened importance when engaging in public political dissent. The competition between opposition groups over resources, membership base and public prominence also involved constant definitions of friendships in relation to those who were considered rivals. Thus, coalition-building among young activists was hindered by rivalries, for instance, between certain Liberal-oriented and Arab Nationalist-oriented youth, yet in the context of everyday interactions, friendship relations were constantly negotiated through the intricate details of everyday practices, and it was often the seemingly mundane things that mattered the most, as Laleh Khalili (2013) also observes of political activists in Lebanon. In Cairo's cafes, as in Beirut's bars, actions such as paying for the rounds of drinks, offering to buy fül (fava bean) sandwiches 'to go' or lending a mobile phone contributed to the daily exchanges that helped to maintain friendship relations. During detention, as we have seen, sharing food with fellow inmates could also contribute to the re-creation of mutual solidarity and reciprocity. Over the Internet, befriending or defriending someone on Facebook, liking and commenting on another's postings or sharing Twitter messages contributed to similar processes of exchange in the virtual spaces. These realms should not be regarded as mutually exclusive but part and parcel of the young activists' everyday existence. In general, if the social and economic exchanges were not reciprocated when the occasion arose to do so, it would be seen in a detrimental light and possibly generate rifts between friends.

\section{Conclusions}

Since 2011, Egypt's state-society relations have gone through profound political, social and economic transformations. Soon after Mubarak's ousting, the Supreme Council of the Armed Forces (SCAF) took on the role of overseeing the transitional period, which witnessed a number of street clashes between young revolutionaries and state authorities. The Muslim Brotherhood and conservative Salafists won the first parliamentary elections in early 2012, and the Brotherhood's Muhammad Mursi was elected president in June 2012. 
The electoral legitimacy of the Islamists was, however, outweighed by popular resentment against the Brotherhood's consolidation of political power, culminating in mass protests on June 30, 2013 which, coupled with the strategic part played by the Military, toppled Mursi from power in July 2013. Much of the Mubarak-era political opposition, including the young activists who featured in this chapter, aligned with this momentum. Since then, the consequent suppression of pro-Mursi protests and Egypt's internal 'war on terror' at the dawn of President Abdel Fattah al-Sisi's term have, however, become highly divisive issues among them: some were supportive of military rule; a few supported the Islamists' claim to political legitimacy; while many were left with even narrower political spaces than those experienced during the late Mubarak era. Amid a heightened sense of nationalism in public life, which also regards street protests as being at the expense of stability, the security apparatus has encroached even further onto their daily interactions both online and offline. In a coinciding development, downtown Cairo no longer offers a similar sense of 'activist life' in its milieus, and even the popular coffee houses of al-Bursa were forced to give way to a parking lot in 2015 .

In this chapter, I focused on the pre-2011 period, and suggested that friendship serves as a fruitful venue for examining the lived experiences of youthful democratic struggle. Engaging in pro-democracy movements and youth coalitions in the late 2000 s provided much more varied experiences for young Cairenes than merely those resulting from the acts of public dissent which represented rather periodic events in their everyday lives. Importantly, being a young activist involved participating in a dissident lifestyle that incorporated sharing moments of being and doing things with others on a daily basis. In the absence of representative political institutions, the experiences of having friends and being a friend to others offered intimate avenues to public political life that stretched beyond kin ties and formal organizations. Although the field of youth activism was divided along lines of class, gender and political affiliation, the young could also forge mutual grounds for friendship relations on the basis of this lifestyle choice, as well as shared tastes and everyday social conduct. The shared experiences, especially those of youthful resistance and injustice, such as those giving rise to prison cell stories, could connect young activists despite the group divisions and ideological strife that was prevalent in the secular-oriented political opposition.

Furthermore, despite the decisive role of the ICTs and social media in mediating friendship relations in the late 200os, the daily need for faceto-face social interactions remained important due to the politicized and policed circumstances in which the young activists lived. Safeguarding the bonds of trust, belonging and everyday solidarity were highly meaningful en- 
gagements. Meanwhile, in the evolving context of youth activism, the shilla formations became the recipients of increasingly ambivalent and negative connotations as vehicles for pursuing personal interests and shared goals while being subject to shifting alliances. Oscillating between the informal and formal areas of public political life, shilal and friendship groups more generally mediated both affective and instrumental connections. Thus, in the runup to 2011, the young activists' engagements did not only relate to sharing dissenting views and the activities against the ruling political elite which resulted. An important aspect of their political engagements was also to learn how to negotiate everyday relations in the context of rapidly shifting alliances, and to manage the public self so as to place it in the least vulnerable position possible.

\section{References}

Abdelrahman, Amr. 2007. "Al-Shabāb wa ḥarakāt al-taghyīr. In Ḥarakāt al-taghyīr aldīmūqrātiyya bayn al-wāqi' wa al-țumūḥ". In Harakāt al-taghyūr al-dīmūqrātiyya bayn al-wāqi' wa al-țumūh, edited by Sameh Fawzi, 177-192. Cairo: Cairo Institute for Human Rights Studies.

Allan, Graham. 1989. Friendship: Developing a sociological perspective. Hemel Hempstead: Harvester Wheatsheaf.

Bell, Sandra and Simon Coleman, eds. 1999a. The anthropology of friendship. Oxford \& New York: Berg.

Bell, Sandra and Simon Coleman. 1999b. "The anthropology of friendship: Enduring themes and future possibilities". In The anthropology offriendship, edited by Sandra Bell and Simon Coleman, 1-19. Oxford \& New York: Berg.

Browers, Michaelle. 2007. "The Egyptian Movement for Change: Intellectual antecedents and generational conflicts". Contemporary Islam 1 (1): 69-88.

Cole, Juan. 2014. The new Arabs: How the millennial generation is changing the Middle East. New York: Simon \& Schuster.

Desai, Amit and Evan Killick, eds. 2013a. The ways of friendship: Anthropological perspectives. Paperback edition. New York \& Oxford: Berghahn Books.

Desai, Amit and Evan Killick 2013b. "Introduction: Valuing friendship." In The ways of friendship:Anthropological perspectives, edited by Amit Desai and Evan Killick, 1-19. New York \& Oxford: Berghahn Books.

Eickelman, Dale F. 2002. The Middle East and Central Asia: An anthropological approach. 4th Edition. New Jersey: Prentice Hall.

El Kadi, Galila and Dalila ElKerdany. 2006. "Belle-époque Cairo: Politics of refurbishing the downtown business district." In Cairo Cosmopolitan: Politics, culture, and urban 
space in the new globalized Middle East, edited by Diane Singerman and Paul Amar, 345-371. Cairo: American University in Cairo Press.

El-Mahdi, Rabab. 2014. Egypt: "A decade of ruptures." In Taking to the streets: The transformation of Arab activism, edited by Lina Khatib and Ellen Lust, $5^{2-75}$. Baltimore: Johns Hopkins University Press.

Fahmi, Wael S. 2009. "Bloggers' street movement and the right to the city: (Re)claiming Cairo's real and virtual 'Spaces of Freedom'." Environment and Urbanization 2 (1): 89-107.

Grätz, Tilo. 2011. "Social-Anthropological Perspectives on Friendship in Africa." In Varieties of friendship, edited by Bernadette Descharmes, Eric Anton Heuser, Caroline Krüger, and Thomas Loy, 355-376. Göttingen: V\&R Unipress.

Herrera, Linda. 2014. "Youth and citizenship in the digital age: A view from Egypt". In Wired citizenship: Youth learning and activism in the Middle East, edited by Linda Herrera and Rehab Sakr, 19-38. New York and Abingdon: Routledge.

Honwana, Alcinda. 2012. The time of youth: Work, social change and politics in Africa. Boulder, CO.: Kumarian Press.

Khalili, Laleh. 2013. "The politics of friendship in times of crisis." Paper presented at the seminar "Is there a secular Middle East?" at Roskilde University, Denmark, February 22.

de Koning, Anouk. 2009. Global dreams: Class, gender, and public space in cosmopolitan Cairo. Cairo: The American University in Cairo Press.

Lynch, Mark. 2007. "Young brothers in the cyberspace." Middle East Report 245. http:// www.merip.org/mer/mer245/young-brothers-cyberspace (accessed 25 January 2016).

Migdal, Joel S. 2001. State in society: Studying how states and societies transform and constituteeach other. Cambridge: Cambridge University Press.

Nederveen Pieterse, Jan. 20o9. Globalization and culture: Global mélange. Lanham: Rowman \& Littlefield Publishers.

Onodera, Henri. 2009. "The kifaya generation: Politics of change among youth in Egypt". Suomen Antropologi: Journal of the Finnish Anthropological Association 34 (4): 44-64.

Onodera, Henri. 2011. "Raise your head high, you're an Egyptian!' Youth, politics, and citizen journalism in Egypt”. Sociologica: Italian Journal of Sociology online 5 (3): 1-22.

Onodera, Henri. 2015. Being ayoung activist: An ethnography of political engagement in Egypt. PhD diss., University of Helsinki, Helsinki.

Sakr, Naomi. 2002. "Seen and starting to be heard: Women and the Arab media in a decade of change." Social Research 69 (3): 821-850.

Schielke, Samuli. 2008. "Boredom and despair in rural Egypt." Contemporary Islam 2 (3): $251-270$. 
Shehata, Dina. 2008. "Youth activism in Egypt." Arab Reform Brief. Arab Reform Initiative. (October 23,2008). http://www.arabreform.net/sites/default/files/ARB.23 _Dina_Shehata_ENG.pdf (accessed 23 January 2016).

Shehata, Dina. 2011. Youth mobilization in Egypt: New trends and opportunities. Issam Fares Institute for Public Policy and International Affairs. Beirut: American University in Beirut.

Shorbagy, Manar. 2007. "The Egyptian Movement for Change - Kefaya: Redefining politics in Egypt". Public Culture 19 (1): 175-196.

Singerman, Diane. 2007. "The economic imperatives of marriage: Emerging practices and identities among youth in Egypt". Middle East Youth Initiative Paper 6/2007. Wolfensohn Center for Development \& Dubai School of Government.

Springborg, Robert. 1975. "Patterns of association in the Egyptian political elite." In Political Elites in the Middle East, edited by George Lenczowski, 83-108. Washington: American Enterprise Institute for Public Policy Research.

Springborg, Robert. 1978. "Professional syndicates in Egyptian politics, 1952-1970". International Journal of Middle Eastern Studies 9 (3): 275-295.

Wickham, Carrie R. 2002. Mobilizing Islam: Religion, activism, and political change in Egypt. New York: Columbia University Press.

Zuhur, Sherifa. 1992. Revealing veiling: Islamist gender ideology in contemporary Egypt. Albany: SUNY Press. 